\section{Oborsky G., Levinsky A., Holofieieva M.}

\title{
THE EFFECT OF SURFACE OBSERVATION ANGLE ON ACCURACY OF NON-CONTACT TEMPERATURE MEASUREMENT METHOD
}

Розглянуто питання підвищення точності вимірювання температури за допомогою приладів інфрачервоної техніки. Актуальним питанням являється дистаниійне вимірювання дійсного значення температури при невідомій випромінювальній здатності тіла, що досліджується. Проведено аналіз основних факторів, що впливають на точність вимірювання температури. Представлено дослідження впливу кута спостереження на коефіцієнт випромінювальної здатності.

ключові слова: температура, похибка вимірювання, інфрачервона техніка, тепловізійний контроль, коефіцієнт випромінювання, термограма.

\section{Introduction}

As we know, the basic industries of Ukraine (metallurgy, chemical industry, construction materials industry and mechanical engineering) are widely use energy-intensive high-temperature processes: melting and surface treatment of metal parts and others. These processes require careful adherence to recommended temperature, because temperature control - the most important and universal means of increasing the process rate and increase the yield of the finished product. Most high-temperature processes occur at temperatures over $900{ }^{\circ} \mathrm{C}$ [1]. However, there are processes that occur at much lower temperatures $\left(250 \ldots 500^{\circ} \mathrm{C}\right)$, but they belong to the high-temperature, because the temperature is a major factor in the intensification of the processes for obtaining maximum yield of the finished product with high technical and economic indicators. So, there is a constant demand for devices and methods for non-contact measurement of as high and relatively low temperatures.

Non-contacting and speed of temperature control by devices that are detected a radiation in the infrared and light range, high resolution, providing detection of local and temporary differences of temperatures on objects of control, visualization of thermal fields are the main advantages of these devices for thermal control [2]. The use of such devices requires paying attention to instrumental and methodical errors that affect the accuracy of temperature measurement.

\section{The object of research and its technological audit}

The object of research is thermal control by infrared devices. A significant disadvantage of optical non-contact temperature measurement methods is the lack of data on the emissivity of real materials in the experiment conditions. This is due to the fact that the ability of the object to emit an infrared radiation can vary because it is depends on the material, properties of the surface, observation direction, and in the case of some materials on temperature.
Technological audit was conducted to identify the variation characteristics of emissivity coefficient in terms of thermal control. The aim of audit was to determine the effect of observation angle on the emissivity coefficient, which in turn leads to inaccurate temperature measurement.

The study was conducted using on thermal imager Fluke Ti9 and auxiliary equipment - tripod, angle finder and personal computer.

The scheme of the measurement process is shown in Fig. 1.

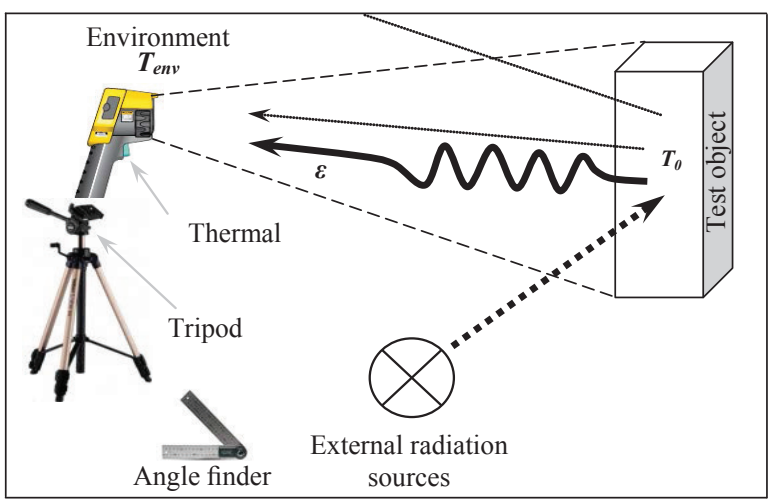

Fig. 1. The scheme of temperature measurement process with a known observation angle

The main direction of this scheme is a calculation of the temperature with the effect of observation angle on emissivity coefficient. This will in practical terms to increase the accuracy of the temperature measurement of the test object.

\section{The aim and objectives of research}

The aim of research is the reduction of methodological error of non-contact temperature measurement method based on the study of the effect of observation angle on emissivity coefficient. 
For this aim in the work it is necessary to solve the following problems:

1. Investigate features of temperature measurement for radiation.

2. Make an analysis of the problems connected with emissivity of materials.

3. Conduct experimental research that confirms the impact angle of observation on the emissivity coefficient.

\section{Research of existing solutions of the problem}

Measurement of the actual temperature in conditions of unknown emissivity is important as held for decades, and despite some progress and success in this direction, issues with a limited amount of information about the emissivity coefficient remain unresolved. Active work and research are conducted in this direction both in Ukraine and abroad.

In particular, [1-3] noted problems and factors arising from the distance temperature measurement, mainly lack of information about emissivity coefficients of surfaces of the test objects. It is shown that emissivity coefficients of heated objects depend on many factors such as geometry and orientation of the emissive surface, its chemical composition, physical condition, presence of contaminants on the surface and so on. It is important to know the physical and chemical state of the surface in terms of measuring because the state and properties of the surface varies with temperature, which is usually accompanied by changes in emissivity.

Dependence of emissivity coefficient of the object on its temperature that is typical for some substances leads to the fact that the full power of thermal radiation of the object depends on its temperature inextricably [4], which complicates non-contact measurement. Certain difficulties are diversity of emitted substances in the IR band that have very different properties from each other: gas and metals, ceramics and plastics, composite materials and dust.

In $[5,6]$ there are dependencies of emissivity of some substances in the IR band on temperature and wavelength. It is shown that the emissivity coefficient of most metals (dielectric) increases (decreases) when heating.

Similar circumstances are noted in [7-10], which reflect the main trends of modern thermometry by radiation and it is concluded about a large number of ways to determine the emissivity coefficient or directly measuring emissivity of the body compared with emissivity of black body at the same temperature, or indirectly by measuring the emissivity coefficients of these bodies. In all cases spurious factors must be considered.

An alternative solution to the problem is presented in [11-13], which offers a temperature measurement using optical devices and contact thermometers. Equality between readings of thermal imager and thermocouple is achieved by changing emissivity value.

It should be noted that in the works there are a large number of ways to determine the emissivity coefficient and which factors affect this, but there are no study of the effect of observation angle on emissivity detected by IR devices.

Thus, the results of the analysis make it possible to conclude that the opportunity to improve the accuracy of temperature measurement by determining the effect of observation angle on emissivity coefficient that detected by IR devices, is the least investigated factor. Therefore, there is a need for more detail consideration.

\section{Methods of research}

Non-contact temperature measurement method is increasingly used in all industries, but to date it is ancillary. Non-contact thermal method is one of the directions of nondestructive testing method and is based on measuring the surface temperature of an object using IR devices.

This method is widely distributed due to a number of advantages over traditional methods. First, a high speed, which is determined by the type of emission detector, and secondly, the ability to control the object without the use of contact measurement methods, thirdly, the ability to document and form an information report, fourthly, the use of feedback as quality level in automatic control systems.

Along with the obvious advantages, thermal imaging methods have a number of disadvantages, which include methodological error that can reach tens of percent using modern IR devices [14]. This leads to errors when interpreting thermograms, disappearance of diagnostic signs of the defect in thermogram or display of non-existent defect.

The main problem that arises in the temperature calculation on the results of thermal imaging measurement is error in surface emissivity assignment of the tested objects [15]. This value is characterized by emissivity coefficient - a numerical value that is equal to the ratio of luminance or brightness of the object at the given temperature and wavelength to the luminance or brightness of black body under the same parameters. Emissivity coefficient of surface of each individual object is individual and depends on many factors including: the size of the object and the distance to it; conditions and type of the surface of the object; roughness of the material; environment, and observation angle.

As already noted, emissivity coefficient depends not only largely on the type and condition of the material, but also on the angle of device to the surface of the object. Dependence on the observation angle has a different kind for metals and dielectrics. If for dielectrics it is approximately follow the Lambert's law (Fig. 2) in the area of normal to the surface and has a maximum value when measured along the normal, then measurement of the surface temperature of most metals most effectively conduct an angle of $20 \div 30^{\circ}$, where emissivity coefficient is maximal. Outside these values, emissivity coefficient decreases rapidly to zero at the tangentially direction of observation [7].

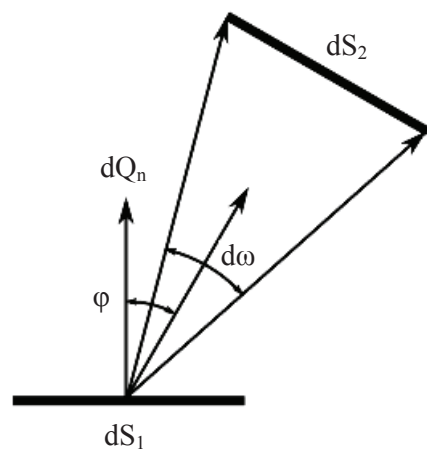

Fig. 2. Lambert's law 
As a result of dependency of emissivity coefficient on observation angle, the effective coefficient of nonplanar surfaces is different at different points, although the material is the same and its rate along the normal is constant.

The actual value of emissivity coefficient can be calculated using the formula:

$$
\varepsilon_{\text {act }}=\frac{\varepsilon_{\text {meas }}}{K_{\text {ang }}}
$$

where $\varepsilon_{a c t}$ - actual value of emissivity coefficient; $\varepsilon_{\text {meas }}-$ measured value of emissivity coefficient; $K_{\text {ang }}-$ coefficient of observation angle effect.

\section{Research results}

Dependencies of $K_{\text {ang }}$ factor on observation angle are obtained.

For metals such dependence is:

$$
K_{\text {ang }}=\left\{\begin{array}{lr}
0,0164 \varphi^{2}-0,1067 \varphi+1,1464, & 0 \leq \varphi \leq 85, \\
-2,53 \varphi+5,06, & 85 \leq \varphi \leq 90,
\end{array}\right.
$$

where $\varphi$ - observation angle.

For dielectrics $K_{\text {ang }}$ dependence on observation angle is most accurately described by the formula:

$$
K_{\text {ang }}=-0,0014 \cdot \varphi^{3}+0,022 \cdot \varphi^{2}-0,1 \cdot \varphi+1,1 .
$$

Using IR devices, an effect of observation angle on accuracy of temperature measurement of the parts made of steel (Fig. 3) and composite material (Fig. 4) were investigated. Determination of temperature was performed directly on the real object, creating data sample:

- actual temperature measured by contact thermometer;

- temperature measured by thermal imager at different observation angles;

- temperature measurement taking into account observation angle.

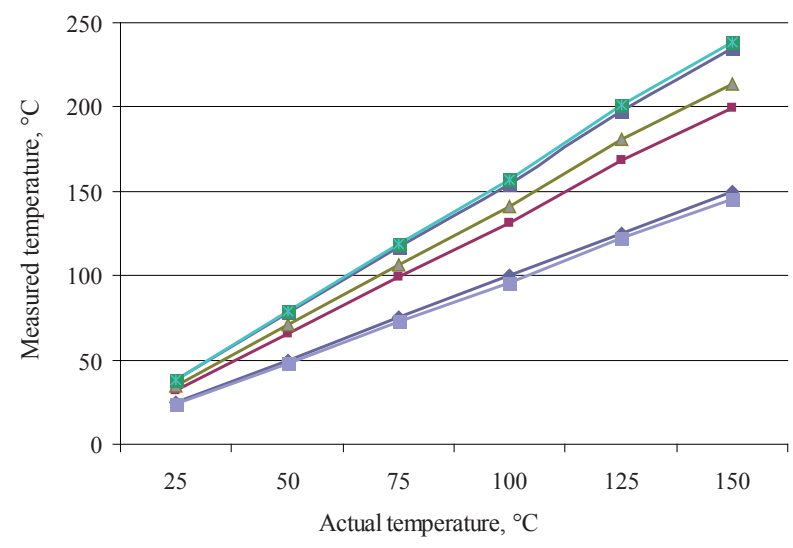

Fig. 3. Effect of observation angle on accuracy of temperature measurement of steel: $\sim$ - actual temperature; $\rightarrow--$ measured temperature (observation angle $60^{\circ}$ ); $\rightarrow--$ measured temperature (observation angle $70^{\circ}$ );

- measured temperature (observation angle 80); $-0-$ measured temperature (observation angle $85^{\circ}$ ); -- measured temperature taking into account an effect of observation angle

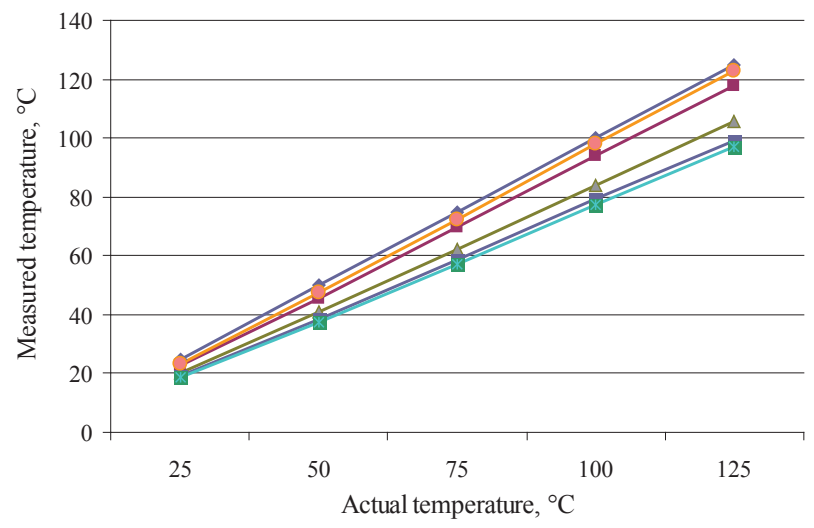

Fig. 4. Effect of observation angle on accuracy of temperature measurement of composite material: $\sim$ - actual temperature; $\rightarrow--$ measured temperature (observation angle 60); -- measured temperature (observation angle $70^{\circ}$ );

- - - measured temperature (observation angle 80); temperature (observation angle $85^{\circ}$ ); $\rightarrow--$ measured temperature taking into account an effect of observation angle

Analysis of the results for effect of observation angle on accuracy temperature measurement, presented in the form of graphs, allow to conclude that measurement error increases with increase of observation angle. The relative error of temperature measurement for parts made of steel at observation angle of $85^{\circ}$ is $57 \%$, and for parts of composite material $-22 \%$. Thus, we can assume that an essential error of measurement makes measurement nonsense. At the same time, effect of the observation angle on measurement accuracy enables reduce a value of absolute error of temperature measurement devices using IR devices to several degrees that in relative form less than $1 \%$.

\section{SWOT analysis of research results}

Strengths. Among the strengths of this research it should be noted results of effect of observation on the accuracy of temperature measurement using IR devices. Presented charts are confirmed this statement that allow to evaluate the precision of temperature measurement. Use of the obtained results regarding different observation angles solves the problem of determining the optimal emissivity coefficient that directly affects the accuracy of temperature measurement.

Weaknesses. Weaknesses of this research are the fact that the solution for accurately temperature measurement using IR devices is due to long-term period. The reason for this is a preliminary angle determination by the angle finder that causes the error.

Opportunities. The main opportunities that achieve the aim of research are that possible control allows to test not only a part or system, and to test individual sections, which in terms of operational reliability can cause the greatest concern. Due to the great potential of control by temperature level, this method can get a wide field of applications in many industries. Since visibility of thermal method, ability to measure the actual temperature values and efficiency in work make it possible to compensate the relatively high price of the equipment.

Threats. Threats that can complicate the process of temperature measurement using IR devices are a variation of emissivity coefficient of the object, which has a significant curvature of the surface and the impossibility of 
its measuring in remote places. It should also be noted that the temperature measurement with small emissivity coefficient leads to some difficulties, namely, separation of natural radiation from the reflected radiation of the background. This leads to the fact that this method can be used at temperatures significantly different from the background, which will reduce the relative energy contribution of background radiation and get a valid temperature data.

Thus, SWOT-analysis of research results can identify the main directions for the successful achievement of the problem. Among them:

- Improvement of the accuracy of temperature measurement based on the effect of observation angle on factor of emissivity coefficient of the object.

- Normalization of images for the purpose of comparability of the thermogram analysis for different sections of the object.

- Selection of possible defective areas on the thermogram based on thermal image method, which will determine the uniformity of thermal field for different objects.

\section{Conclusions}

1. It is investigated that temperature measurement by radiation is one of the main directions of development of high-performance diagnostic system that provides the ability to control the thermal state of the object, finds defects at an early stage of their development and minimize the cost of maintenance.

2. It is established that one of the significant factors affecting the accuracy of temperature measurement is the emissivity of the surface of the test object. Emissivity coefficient is mostly presented in tables or presented in the form of graphs. In general, emissivity coefficient depends on the type of material, wavelength, temperature, surface condition and observation angle of object surface. The data given in the tables are very significant difference. Therefore, the temperature dependence of emissivity coefficient allow for more accurate temperature measurement of the object.

3. It is found that the errors in setting emissivity coefficient are significantly affecting the accuracy of temperature measurement using IR devices. Researches of an influence of observation angle on accuracy of temperature measurement of steel and polymer composite products show that when the angle of observation is changed, then temperature measurement error of thermal imager can exceed $50 \%$, making measurements nonsense. A dependency, allowing reduced value of absolute error of temperature measurement using IR devices to several degrees that in relative form less than $1 \%$, are proposed.

\section{References}

1. Svet, D. Ya. Obiektivnye metody vysokotemperaturnoi pirometrii pri nepreryvnom spektre izmereniia [Text] / D. Ya. Svet. Moscow: Nauka, 1968. - 236 p.

2. Oborsky, G. O. Vymiriuvannia neelektrychnykh velychyn [Text]: Textbook / G. O. Oborsky, P. T. Slobodianyk. - Kyiv: Nauka i tekhnika, 2005. - 200 p.

3. Bramson, M. A. Infrakrasnoe izluchenie nagretyh tel [Text] / M. A. Bramson. - Moscow: Nauka, 1965. - Vol. 1. - 224 p.

4. Jacyszun, S. Efekty szumowe w termometrii [Text] / S. Jacyszun, B. Stadnyk, J. Lucyk, F. Skoropad // Pomiary, automatyka, kontrola. - 2003. - Vol. 49, № 7/8. - P. 15-17.
5. Valancius, K. Transient heat conduction process in the multilayer wall under the influence of solar radiation [Text]: Proceedings / K. Valancius, A. Skrinska // Improving human potential program. - Almeria, Spain: PSA, 2002. - P. 179-185.

6. Minkina, W. Pomiary termovizyne-przyrzdy i metody [Text] / W. Minkina. - Czestochova: Wydawnictwo Politechniki Częstochowskie, 2004. - 243 p.

7. Vavilov, V. P. Infrakrasnaia termografiia i teplovoi kontrol' [Text]/ V. P. Vavilov. - Moscow: ID Spektr, 2009. - 544 p.

8. Svet, D. Ya. Opticheskie metody izmereniia istinyh temperatur [Text] / D. Ya. Svet. - Moscow: Nauka, 1982. - 296 p.

9. Gordov, A. N. Osnovy pirometrii [Text] / A. N. Gordov. Ed. 2. - Moscow: Metallurgiia, 1971. - 448 p.

10. Gossorg, J. Infrakrasnaia termografiia. Osnovy, tehnika, primenenie [Text]: Translation from French / J. Gossorg. - Moscow: Mir, 1988. - 416 p.

11. Bernhard, F. Technische Temperaturmessung [Text] / F. Bernhard. - Springer, 2004. - 1460 p. doi:10.1007/978-3-642-18895-4

12. Lynnworth, L. C. Ultrasonic Thermometry [Text] / L. C. Lynnworth, E. P. Papadakis // Ultrasonics Symposium. - 1970. P. 83-93. doi:10.1109/ultsym.1970.196006

13. Vvedenie v termografiiu [Text] / American Technical Publishers, Inc., Fluke Corporation, и The Snell Group. - Russia, 2009. Available at: \www/URL: http://www.thermoview.ru/pdf/ flukeguide.pdf. - 10.02.2016.

14. Gerashchenko, O. A. Teplovye i temperaturnye izmereniia [Text]: Reference Manual / O. A. Gerashchenko, V. G. Fedorov. Kyiv: Naukova dumka, 1965. - 304 p.

15. Oborsky, G. Researching the materials emissivity influence onto the thermal control method's accuracy [Text] / G. Oborsky, A. Levinsky, M. Holofieieva // Technology Audit And Production Reserves. - 2016. - № 2/3 (28). - P. 4-7. doi:10.15587/23128372.2016 .61802

\section{ВЛИЯНИЕ УГЛА НАБЛЮДЕНИЯ ПОВЕРХНОСТИ НА ТОЧНОСТЬ БЕСКОНТАКТНОГО МЕТОДА ИЗМЕРЕНИЯ ТЕМПЕРАТУРЫ}

Рассмотрены вопросы повышения точности измерения температуры с помощью приборов инфракрасной техники. Актуальным вопросом является дистанционное измерение действительного значения температуры при неизвестной излучательной способности испытуемого тела. Проведен анализ основных факторов, влияющих на точность измерения температуры. Представлено исследование влияния угла наблюдения на коэффициент излучательной способности.

ключевые слова: температура, погрешность измерения, инфракрасная техника, тепловизионный контроль, коэффициент излучения, термограмма.

Oborsky Gennady, Doctor of Technical Sciences, Professor, Department of Machine Tools, Metrology and Certification, Odessa National Polytechnic University, Ukraine, ORCID: http://orcid.org/ 0000-0002-5682-4768

Levinskiy Aleksandr, Postgraduate student, Department of Machine Tools, Metrology and Certification, Odessa National Polytechnic University, Ukraine, e-mail: Levinskiy.a.s@gmail.com, ORCID: http://orcid.org/0000-0001-9643-1494

Holofieieva Maryna, PhD, Department of Machine Tools, Metrology and Certification, Odessa National Polytechnic University, Ukraine, ORCID: http://orcid.org/0000-0002-7632-9027 